\title{
An experimental study of solar thermal system with storage for domestic applications
}

\author{
M. Abid' 1 , B. A. A. Yousef ${ }^{2}$, M. E. Assad ${ }^{2}$, A. Hepbasli ${ }^{3}$ and K. Saeed ${ }^{4}$ \\ ${ }^{1}$ Center for Sustainable Technologies, Ulster University, Newtownabbey, BT37 0QB, \\ UK. \\ ${ }^{2}$ Sustainable and Renewable Energy Engineering, College of Engineering, University of \\ Sharjah, Sharjah, UAE \\ *Email: byousef@sharjah.ac.ae \\ ${ }^{3}$ Department of Energy Systems Engineering, Faculty of Engineering, Yasar University, \\ Bornova,35100 Izmir, Turkey \\ ${ }^{4}$ Department of Mechanical Engineering, College of Engineering, King Saud University \\ Riyadh, Kingdom of Saudi Arabia.
}

\begin{abstract}
Building sector consumes a greater portion of energy for heating and cooling applications. The utilization of fossil fuels for space and water heating in buildings cause a negative effect on the environment by producing larger $\mathrm{CO}_{2}$. In this study solar thermal water heating system for building application have been analyzed from the first and second law perspectives of thermodynamics considering various scenarios and water consumption pattern. The solar flat collector is very commonly used to extract energy from sunlight. Therefor energy and exergy efficiency curves for the solar flat collector were presented. The energetic and exergetic values for the system were calculated based on the experimental values for the overall system, the heat exchanger and the pumps using the approach of exergetic product/fuel basis. The greatest and lowest relative irreversibility's occurred at the solar collector and the heat exchanger with values of $85.73 \%$ and $2.45 \%$, respectively, and the system overall exergy efficiency was determined to be $20.28 \%$. The energy and exergy efficiencies of the solar collector were analyzed at three different cases depending on the mass flow rates in the solar collector and the secondary circuit of the system. Three different mass flow rates were applied to the inlet of the secondary circuit to observe the efficiency effect on the solar collector circuit. This study can assist in selecting a proper solar collector and storage size for buildings of various capacity and possible improvement in the design of the system components.
\end{abstract}

Keywords: Flat solar collector; Energy, Exergy; Improvement potential rate; Sustainability.

\section{INTRODUCTION}

Green energy is considered renewable and sustainable. Two basic technologies are used to receive energy from the sun: one is solar Photovoltaics, and another is solar thermal collectors. Recently, solar power generation percentage has grown even more rapidly, but from a very smaller base. European Union has set a target to achieve a 20\% share by 2020 of renewable energy sources in final energy consumption. To achieve these goals, the solar thermal sector could provide an important contribution, since the demand for heating and domestic hot water production accounts for $37 \%$ of the total energy demand 
in Europe [1]. The main problem associated with the use of this energy is its low grade and high initial cost. The efficiency of the systems operated on the solar energy is very low compared to the conventional systems available in the market. Solar collectors are very common and have been used for heating air and water according to the required application [2-5]. Energy and exergy analyses of flat plate collectors have been carried out by many researchers [6-9]. Optimum tilt angle determination of solar collectors with respect to nearby buildings shadow have also been investigated [10]. Life cycle analysis of solar water heating system in United Kingdom has been presented for region with low solar irradiance. The study revealed that solar water heating system is not a suitable option for implementation in UK due to the low potential of solar irradiation [11]. One way to improve solar water heating system performance can be achieved by adding a solar tracker of solar irradiation [12]. An experiment setup has been built for this purpose, where it was demonstrated that inclination of solar collector has the capability of improving $40 \%$ gain depending on the season. The three components of the energy system considered were solar collector, heat exchanger, and energy storage.

Another way to improve solar heating system performance is to use phase change material (PCM) as an energy storage medium [13]. The performance of the system; efficiency, coefficient of performance (COP) and water outlet temperature was analyzed with and without PCM. The results showed through an experimental study that using PCM and oscillating heating pipe was an efficient in solar energy applications because the exit water temperature was kept above $50^{\circ} \mathrm{C}$ at night for a longer time than without PCM. Nano particles also used instead of simple water glycol solution to improve the efficiency of the collector [14]. In [14] study the efficiency improved to 0.73 by using Nano-fluid instead of using only water which is about 0.58 . The researchers did not change the flow rates and was fixed at 2.7 liters per minute. Heat transfer coefficient could also be improved by using nanomaterials [15] and forced convection technique [16].

A techno-economic analysis of solar water heating system presented by Mehdi et al [17] to determine the influence of the key factors on the payback period. The study demonstrated useful information to apply solar water heating systems in various application i.e. Domestic hot water and space heating purposes with tecno-economic improvement in the system performance. Various water consumption pattern has been considered. Typical house located in Shiraz city of Iran have been considered as a case study. The optimum maximum ratio between storage tank volume and collector area was $0.08 \mathrm{~m}$ to get $90 \%$ of solar contributions. The overall heating system was supported by electricity and natural gas. The cases of supplying heat energy only for domestic purposes and combined with space heating were considered individually for the economic evaluation's purposes.

The decarbonization of the heating sector at domestic level which consumes $50 \%$ of the energy supplied in EU countries and the major portion is coming from fossil fuels [18]. It has been emphasized in the report to increase the renewable energy sources effective use at domestic level. The solar thermal heating system with storage employed for the retrofitting purposes or the new build houses purposes needs proper design \& selection of the main components. Therefore, in this study an effort has been made to select design and select proper components according to the building requirements by having information from the weather data and the water consumption pattern. The system can be useful to be employed with other renewable energy sources like heat pump, PV, Cogeneration to have a polygeneration system [19]. In this way maximum contribution will be coming from renewable sources. The energy storage can assist a negative impact on the grid. None of the above-mentioned works did an exergy analysis combined with 
cost of the thermodynamic loss of solar water heating system based on experimental results in such a comprehensive and detailed methods to the best of authors knowledge. Exergy analysis is a good tool to analyze energy system and gives an idea of real losses in the system. The study provides very useful information and thermodynamic modeling of the solar water heating system which has the flexibility to apply different system. In this work, an experimental setup of solar water heating system powered by controlled laboratory light source to determine the effect of mass flow rates in the solar collector (primary circuit) and the secondary circuit (storage circuit) on the system performance is presented. The performance of each component of the system has been analyzed using energy and exergy analyses for which three different scenarios are considered.

\section{METHODS AND MATERIALS}

The solar thermal water heating system under investigation is a closed-circuit system. The main components of the system are solar collector, heat exchanger, storage tank and pump. Figure 1 shows the schematic diagram and the experimental set up. Table 1 gives the specification details for the system. A laboratory controlled light source is used to simulate the solar radiation that falls on flat plate collector and heats the absorber plate. The absorber plate heats the circulating working fluid through convection process. The heated fluid leaves the collector to the heat exchanger. In the heat exchanger, the thermal energy of the working fluid in the solar circuit is transferred to the water in the secondary circuit, which is directly connected to the inlets and outlets of the storage tank. The pump in the solar circuit then pumps the cooled heat transfer fluid from the heat exchanger back to the flat collector, creating a closed solar circuit.

Table 1. Solar thermal water heating System specification.

\begin{tabular}{|c|c|c|}
\hline S. No. & $\begin{array}{c}\text { Solar thermal Water heating system } \\
\text { Component/Properties }\end{array}$ & Specifications/Range \\
\hline 1 & Length $\mathrm{x}$ Width $\mathrm{x}$ Height & $2.3 * 0.8 * 2.2 \mathrm{~m}$ \\
\hline 2 & Power consumption & $130 \mathrm{~W}$ \\
\hline 3 & Operating pressure in the solar circuit & Maximum $600 \mathrm{kPa}$ \\
\hline 4 & Flow rate range for the solar water circuit & $0-0.041 \mathrm{~kg} / \mathrm{s}$ \\
\hline 5 & Absorbing surface area & $2.31 \mathrm{~m}^{2}$ \\
\hline 6 & Working fluid(water) & $0.00141 \mathrm{~m}^{3}$ \\
\hline 7 & Pressure loss at $0.0138 \mathrm{~kg} / \mathrm{second}$ & $10 \mathrm{kPa}$ \\
\hline 8 & Pressure relief valve in the solar circuit & $500 \mathrm{kPa}$ \\
\hline 9 & Temperature measurement range for thermometer & $0-160{ }^{\circ} \mathrm{C}$ \\
\hline 10 & Pump power consumption in the solar circuit & $13 \mathrm{~W}$ \\
\hline 11 & Maximum flow rate for the secondary circuit & $0.833 \mathrm{~kg} \mathrm{~s}^{-1}$ \\
\hline 12 & Storage tank capacity & $0.14 \mathrm{~m}^{3}$ \\
\hline 13 & Rotameter measurement range & $0.0055-0.088 \mathrm{~kg} \mathrm{~s}^{-1}$ \\
\hline 14 & Humidity sensor Measuring range & $\begin{array}{l}0.0-100 \% \text { with } \pm 2.5 \% \\
\text { accuracy. }\end{array}$ \\
\hline
\end{tabular}




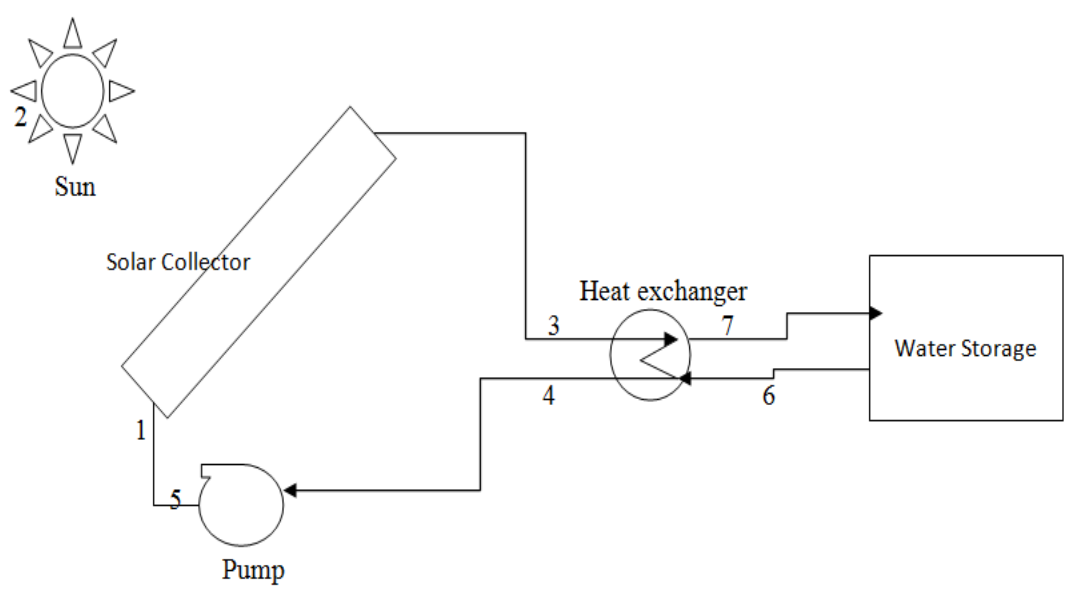

(a)

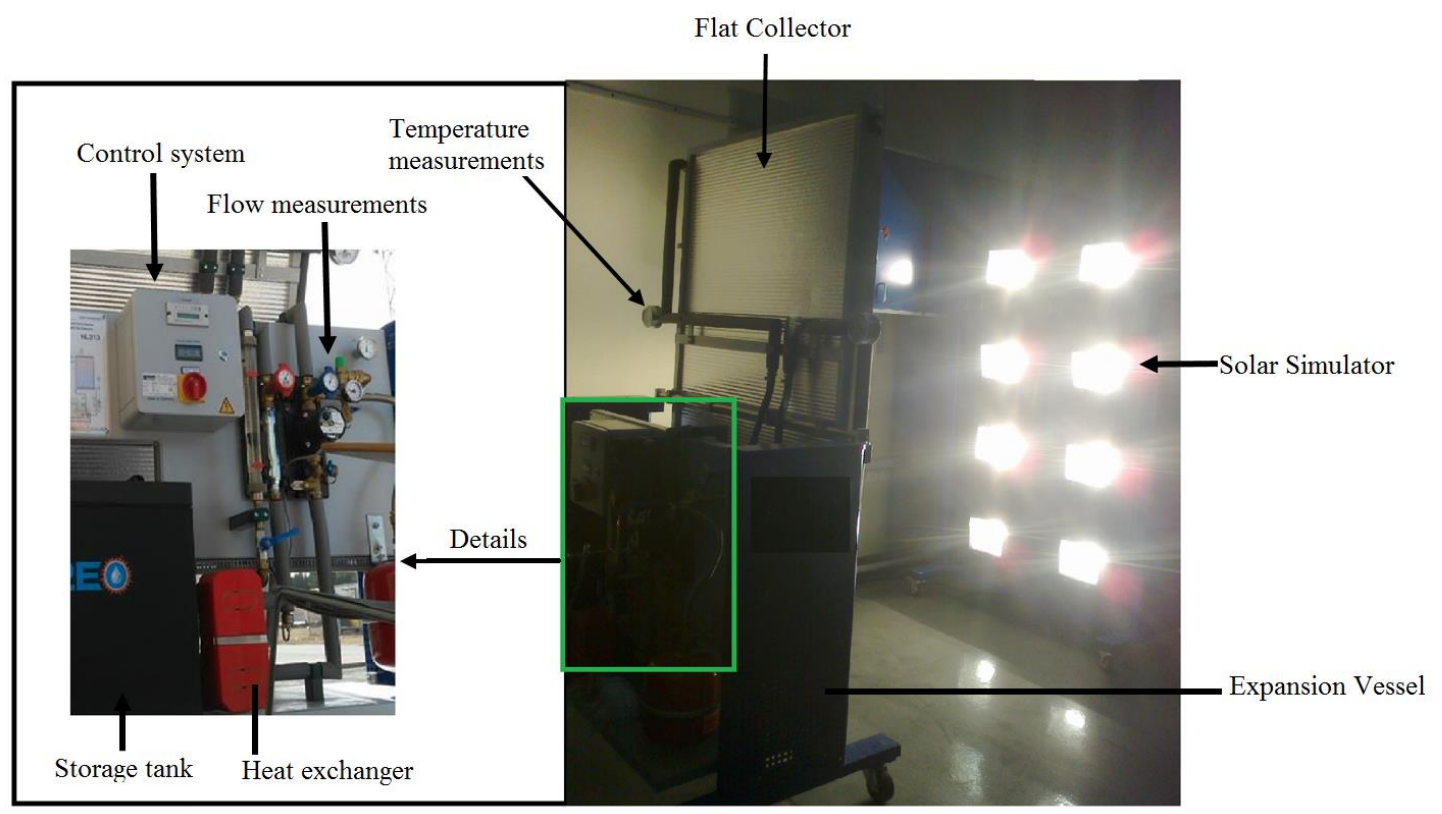

(b)

Figure 1. a) Schematic diagram for the solar thermal water heating system, b) Experimental Setup.

To adjust the angle of inclination, the collector is mounted on a pivot-able frame. Bimetallic thermometer with mechanical indicator and electrical resistance thermometer with connection to the data acquisition system are used to measure the temperatures. The manometer is used to monitor the pressure in the solar circuit. The expansion vessel in the solar circuit is used to hold the increasing volume of heat transfer fluid as the temperature rises. This makes it possible to keep the pressure almost constant above a given temperature range. A solar cell with a known sensitivity is provided for the measurement of luminance. The solar cell is mounted on a holder and is movable, which makes it possible to take luminance measurements at different locations. The flow rate in the solar circuit is measured using a rotameter. The sight glass of the rotameter can also be used to check residual air bubbles in the solar circuit during the filling process.

The following cases were considered in this study; 
i. The first case, the storage tank was filled with $0.06 \mathrm{~m}^{3}$ of water to see the time dependency of the outlet power, inlet and outlet temperatures of the solar flat collector.

ii. The second case included the tank filled with water, which was maintained at a constant temperature of $30^{\circ} \mathrm{C}$ and continuously flushed out to attain the steady state condition. Six different mass flow rates were applied to find the optimum mass flow rate for the system performance. The system overall performance, exergetic and energetic rate analysis, and some thermodynamics parameters were investigated at the optimum mass flow rate.

iii. The third case considered was the effect of varying mass flow rate in the secondary circuit on the system performance.

General relation for the energy and exergy analysis of the solar thermal water heating system is presented for its performance evaluation.

The mass balance equation can be expressed in the rate form as follows;

$$
\sum \dot{m}_{\text {in }}=\sum \dot{m}_{\text {out }}
$$

According to the first law of thermodynamics, the general energy balance expressed by equation (2) as the total energy input rates equal to total energy output rates,

$$
\sum \dot{E}_{\text {in }}=\sum \dot{E}_{\text {out }}
$$

The general exergy balance expressed in the rate form by the following equations,

$$
\begin{aligned}
& \sum \dot{E} x_{\text {in }}-\sum \dot{E} x_{\text {out }}=\sum \dot{E} x_{\text {destructia }} \\
& \dot{E} x_{\text {heat }}-\dot{E} x_{\text {work }}+\dot{E} x_{\text {mass, in }}-\dot{E} x_{\text {mass,out }}=\dot{E} x_{\text {destructia }}
\end{aligned}
$$

With

$$
\dot{E} x_{\text {heat }}=\sum\left(1-\frac{T_{0}}{T_{k}}\right) \dot{Q}
$$

whereas $\dot{Q}$ the heat transfer rate through the boundary at temperature $\mathrm{T}_{\mathrm{k}}$ at location $\mathrm{k}$. The specific exergy is given as follows;

$$
\psi=\left(h-h_{0}\right)-T_{0}\left(s-s_{0}\right)
$$

\section{Energy and exergy efficiencies}

The instantaneous thermal efficiency of the solar collectors is given by the following equation $[20,21]$.

$$
\eta_{s c o l}=\frac{\dot{Q}_{u}}{A_{s c o l} G_{T}}=\left(\frac{\dot{m}_{f} C_{p, f}\left(T_{2}-T_{1}\right)}{A_{s c o l} G_{T}}\right)
$$

Exergy efficiency given as 


$$
\varepsilon=\frac{\dot{E} x_{\text {output }}}{\dot{E} x_{\text {input }}}=1-\frac{\dot{E} x_{\text {destructia }}}{\dot{E} x_{\text {input }}}
$$

The exergy efficiency on the exergetic product/exergetic fuel basis for the whole system and individual components can be expressed as follows;

$$
\varepsilon_{\text {system }}=\frac{\dot{P}}{\dot{F}}
$$

\section{Solar collector}

The instantaneous exergy efficiency can be defined as the ratio of the increased water exergy to the exergy of the solar radiation [22]

$$
\varepsilon_{\text {scol }}=\frac{\dot{E} x_{u}}{\dot{E} x_{s o l}}
$$

Where

$$
\dot{E} x_{u}=\dot{m}_{f, o u t}\left[\left(h_{2}-h_{1}\right)-T_{0}\left(s_{2}-s_{1}\right)\right]=\dot{m}_{f} c_{p, f}\left[\left(T_{2}-T_{1}\right)-T_{0}\left(\operatorname{Ln} \frac{T_{2}}{T_{1}}\right)\right]=\dot{Q}_{u}\left[1-\frac{T_{o}}{T_{2}-T_{1}}\left(\operatorname{Ln} \frac{T_{2}}{T_{1}}\right)\right]
$$

The exergy of solar radiation $\dot{E} x_{\text {sol }}$ can be expressed in terms of total solar irradiance $\left(\mathrm{G}_{\mathrm{t}}\right)$,

$$
\dot{E} x_{\text {solar }}=A G_{t} \psi_{\text {srad }}=A G_{t}\left[1-\frac{4}{3}\left(\frac{T_{0}}{T_{\text {sun }}}\right)+\frac{1}{3}\left(\frac{T_{0}}{T_{\text {sun }}}\right)^{4}\right]
$$

Where $\mathrm{T}_{\text {sun }}$ was taken equal to $6000 \mathrm{~K}$ by other researchers [23].

\section{Exergy analysis of pump and heat exchanger}

Exergy destructions in the pump exergy efficiency given as follows [24].

$$
\begin{gathered}
\dot{E} x_{\text {dest, pump }}=\dot{W}_{\text {pump,elect }}+\dot{m}_{f}\left(\psi_{\text {out }, \text { act }}-\psi_{\text {in }, a c t}\right) \\
\varepsilon_{\text {pump }}=\frac{\dot{E} x_{\text {act,out }}-\dot{E} x_{i n, a c t}}{\dot{W}_{\text {pump }, \text { elect }}}=\frac{\dot{m}_{f}\left(\psi_{\text {act,out }}-\psi_{\text {act }, \text { in }}\right)}{\dot{W}_{\text {pump,elect }}}
\end{gathered}
$$

The exergy destruction rate for the heat exchanger is given by the following relationship;

$$
\dot{E} x_{\text {dest }, H . E}=\dot{m}_{h o t}\left(\psi_{3}-\psi_{4}\right)-\dot{m}_{\text {cold }}\left(\psi_{6}-\psi_{7}\right)
$$

with exergy efficiency as given below;

$$
\varepsilon_{H . E}=\frac{\dot{E} x_{6}-\dot{E} x_{7}}{\dot{E} x_{3}-\dot{E} x_{4}}=\frac{\dot{m}_{c o l d}\left(\psi_{6}-\psi_{7}\right)}{\dot{m}_{h o t}\left(\psi_{3}-\psi_{4}\right)}
$$




\section{Relative irreversibility}

The relative irreversibility for each component and the system calculated using the following relationship;

$$
\text { Re lative irreversibility }(R I)=\frac{\dot{E} x_{\text {dest }, i}}{\dot{E} x_{\text {dest, total }}}
$$

\section{Sustainability assessment}

The Sustainability Index SI method based on exergy efficiency is a useful tool to obtain sustainability assessment given by the following equation;

$$
S I=\frac{1}{1-\varepsilon}
$$

\section{Exergetic improvement potential}

The improvement potential rate denoted by $I \dot{P}$ is given by the following relationship [25].

$$
I \dot{P}=(1-\varepsilon) *\left(\dot{E} x_{\text {in }}-\dot{E} x_{\text {out }}\right)
$$

\section{RESULTS AND DISCUSSION}

The mathematical modelling presented in the previous section have been applied to get the results. The system energy and exergy efficiencies component by component have been calculated and any irreversibility's have been quantified. The exergetic improvement potential, sustainability index was calculated which are very important parameter and have been used by other researcher [26] for the energy system improvements. The pressure, temperature, humidity, flow rates, solar irradiation and other parameters have been measured by the above-mentioned devices. The energy and exergy rates for the system using water as a working fluid are presented in Table 2 for one representative value according to the state points. The thermodynamic properties, namely specific enthalpy and specific entropy of water are found using Cycle pad software package program. The reference state is taken equal to $25^{\circ} \mathrm{C}$ and $101.325 \mathrm{kPa}$.

Table 3 shows the irreversibility contributed by each component and the overall system and the exergy efficiency on the exergetic product fuel basis. It also shows relative irreversibility, sustainability index and improvement potential rate for the system. The storage tank temperature, temperature at the inlet and outlet, thermal output vs. time have been shown in Figure 2.

The storage tank temperature can reach up to $70{ }^{\circ} \mathrm{C}$ depending on the inlet, outlet temperature and the applied irradiance. The heated water can be used for later use for different applications. The radiators for space heating in the old buildings which are high temperature based can be operated directly by connecting to the storage. Additionally, the it can be used for Domestic hot water purposes which are safe until $55{ }^{\circ} \mathrm{C}$ to avoid any skin burning according to the health and safety regulations. A small fluctuation is noted at the start in the inlet and outlet temperature and then after some time it get steadily rise.

Table 2. Energetic and exergetic data for one optimum value 


\begin{tabular}{|c|c|c|c|c|c|c|c|c|c|}
\hline no & Comp. & $\begin{array}{l}\text { Temp. } \\
\left({ }^{\circ} \mathrm{C}\right)\end{array}$ & $\begin{array}{l}\text { Press. } \\
(k P a)\end{array}$ & $\begin{array}{l}\text { Specific } \\
\text { enthalpy } \\
(\mathbf{k J} / \mathbf{k g})\end{array}$ & $\begin{array}{l}\text { Specific } \\
\text { entropy } \\
(\mathrm{kJ} / \mathrm{kg} . \mathrm{K})\end{array}$ & $\begin{array}{l}\text { Mass flow } \\
\text { rate } \\
(\mathrm{kg} / \mathrm{s})\end{array}$ & $\begin{array}{l}\text { Specific } \\
\text { exergy } \\
(\mathbf{k J} / \mathbf{k g})\end{array}$ & $\begin{array}{l}\text { Exergy } \\
\text { rate } \\
(\mathbf{k W})\end{array}$ & $\begin{array}{l}\text { Energy } \\
\text { rate } \\
(\mathbf{k W})\end{array}$ \\
\hline 0 & & $\begin{array}{l}\text { Ref. } \\
\text { state }\end{array}$ & 101.32 & 104.8 & 0.3669 & - & - & - & - \\
\hline 1 & $\begin{array}{l}\text { Collector } \\
\text { inlet }\end{array}$ & 38.12 & 245.25 & 159.9 & 0.546 & 0.022 & 1.433 & 0.0315 & 3.517 \\
\hline 2 & $\begin{array}{l}\text { Collector } \\
\text { outlet }\end{array}$ & 50.32 & 245.25 & 210.9 & 0.7 & 0.022 & 6.517 & 0.1433 & 4.639 \\
\hline 3 & HE inlet & 49.15 & 245.25 & 206 & 0.692 & 0.022 & 4.004 & 0.0880 & 4.532 \\
\hline 4 & $\begin{array}{l}\text { HE outlet/ } \\
\text { pump } \\
\text { inlet }\end{array}$ & 37.51 & 245.25 & 157.3 & 0.538 & 0.022 & 1.218 & 0.0267 & 3.460 \\
\hline $5 s$ & $\begin{array}{l}\text { Pump } \\
\text { outlet/ } \\
\text { collector } \\
\text { inlet }\end{array}$ & 37.83 & 245.25 & 158.6 & 0.543 & 0.022 & 1.028 & 0.0226 & 3.489 \\
\hline $\begin{array}{l}5 \mathrm{a} \\
\mathrm{ct}\end{array}$ & $\begin{array}{l}\text { Pump2 } \\
\text { outlet/coll } \\
\text { ector inlet }\end{array}$ & 38.12 & 245.25 & 159.9 & 0.546 & 0.022 & 1.433 & 0.0315 & 3.517 \\
\hline 6 & $\begin{array}{l}\text { Cold } \\
\text { water to } \\
\mathrm{HE}\end{array}$ & 27.5 & 101.32 & 115.3 & 0.402 & 0.048 & 0.124 & 0.0059 & 5.534 \\
\hline 7 & $\begin{array}{l}\text { Hot water } \\
\text { to storage } \\
\text { tank }\end{array}$ & 35.61 & 101.32 & 149.2 & 0.513 & 0.048 & 0.811 & 0.0389 & 7.161 \\
\hline
\end{tabular}

Table 3. Component Irreversibility's rates and thermodynamic parameters for one representative unit of the solar water heating system analyzed.

\begin{tabular}{llllllll}
\hline $\begin{array}{l}\text { Comp. } \\
\text { Name }\end{array}$ & $\begin{array}{l}\text { Irreversibility } \\
\text { rate }(\mathbf{k W})\end{array}$ & $\begin{array}{l}\text { Exergetic } \\
\text { product } \\
\text { rate } \\
\mathbf{( k W )}\end{array}$ & $\begin{array}{l}\text { Exergetic } \\
\text { fuel rate } \\
(\mathbf{k W})\end{array}$ & $\begin{array}{l}\text { Exergy } \\
\text { efficiency } \\
(\boldsymbol{\%})\end{array}$ & $\begin{array}{l}\text { Relative } \\
\text { irreversibility } \\
(\boldsymbol{\%})\end{array}$ & $\begin{array}{l}\text { Sust. } \\
\text { index }\end{array}$ & $\begin{array}{l}\text { Improvement } \\
\text { potential rate } \\
(\mathbf{k W})\end{array}$ \\
\hline $\begin{array}{l}\text { Solar } \\
\text { collector }\end{array}$ & 0.990 & 0.111 & 0.859 & 13.01 & 85.73 & 1.149 & 0.862 \\
$\begin{array}{l}\text { Heat } \\
\text { exchanger }\end{array}$ & 0.028 & 0.066 & 0.094 & 69.86 & 2.45 & 3.317 & 0.009 \\
$\begin{array}{l}\text { Pump } \\
\text { Overall }\end{array}$ & 0.137 & 0.037 & 0.1 & 37.15 & 11.86 & 1.587 & 0.087 \\
system & 1.155 & 0.214 & 1.053 & 20.28 & 100.00 & 1.254 & 0.921 \\
\hline
\end{tabular}

The calculated thermal power first reaches values above $492.5 \mathrm{~W}$ and increases significantly at higher temperatures Essentially one can already deduce from the results that in terms of the achieved thermal power, it is advantageous to operate the flat collector at lowest possible temperatures. The demand side management which is a comprehensive program for the efficient utilization of the current resources can be promoted by having a 
thermal storage at domestic level. The energy stored in the tank during the day time could be used for later use specifically at the time of high demand.

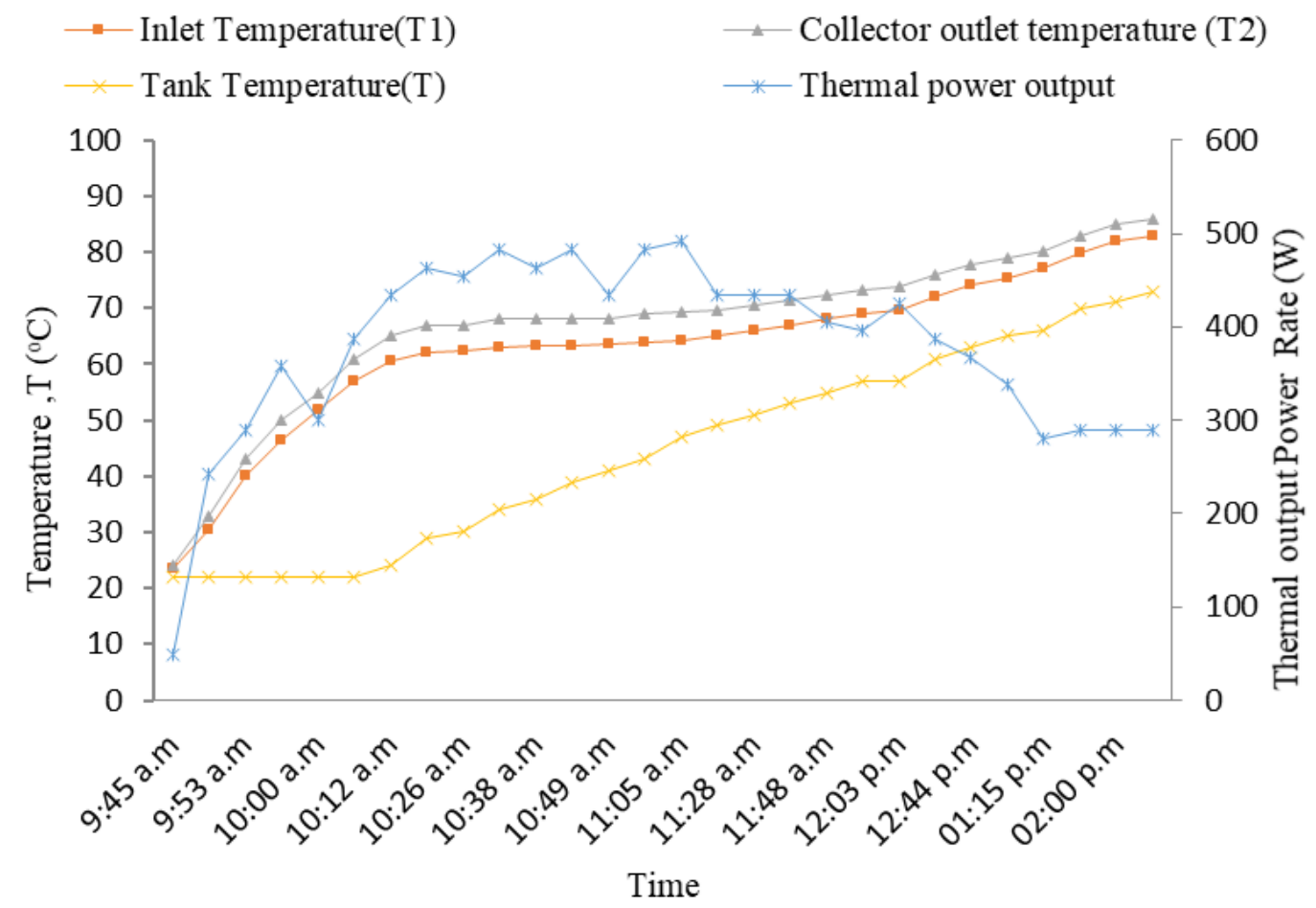

Figure 2. Thermal output power, inlet, outlet and tank temperature behavior vs. time. The water consumption and the flow rates pattern in different types of buildings can be helpful to customize such systems. By having information of the requirements, the system flow rates can be settled accordingly, and the storage temperature can be increased or decreased for later use. For example, in one of our case shown in Figures 3 and 4 when the tank is filled and continuously flushed out and the temperature is maintained at $30{ }^{\circ} \mathrm{C}$. Six different mass flow rates in the solar collector circuit were used in the analysis. The mass flow rate was changed in the primary circuit and the system could get into steady state condition. As can be seen from Figure 3 that the inlet temperature has minimum and maximum values of $57.5^{\circ} \mathrm{C}$ and $68.2^{\circ} \mathrm{C}$ for the flow rates of $0.0055 \mathrm{~kg} / \mathrm{s}$ and $0.033 \mathrm{~kg} / \mathrm{s}$, respectively, while the outlet temperature has minimum and maximum values of $73{ }^{\circ} \mathrm{C}$ and $84{ }^{\circ} \mathrm{C}$ for the flow rates of $0.033 \mathrm{~kg} / \mathrm{s}$ and $0.0055 \mathrm{~kg} / \mathrm{s}$, respectively. The difference in temperatures at the inlet and outlet decreases with the increase in the mass flow rate. 




Figure 3. Mass flow rate in the solar collector circuit, inlet, outlet and tank temperature vs. time.

Figure 4 shows the thermal efficiency and mass flow rate in the solar circuit effect on the temperature difference between the inlet and outlet collector temperature difference. The thermal efficiency has maximum and minimum values of $65.71 \%$ and $54.41 \%$ at temperature differences of $8{ }^{\circ} \mathrm{C}$ and $26.5{ }^{\circ} \mathrm{C}$, respectively. The maximum efficiency is attained at a flow rate of $0.022 \mathrm{~kg} / \mathrm{s}$ and the efficiency is minimum at the lowest flow rate. The thermal efficiency increases with the increase in the flow rate until it reaches maximum at $0.022 \mathrm{~kg} / \mathrm{s}$ and after that point the increase in flow rate have negative impact on the thermal efficiency of the solar flat collector. As can be seen from the graph that the temperature for the tank water remains constant. 


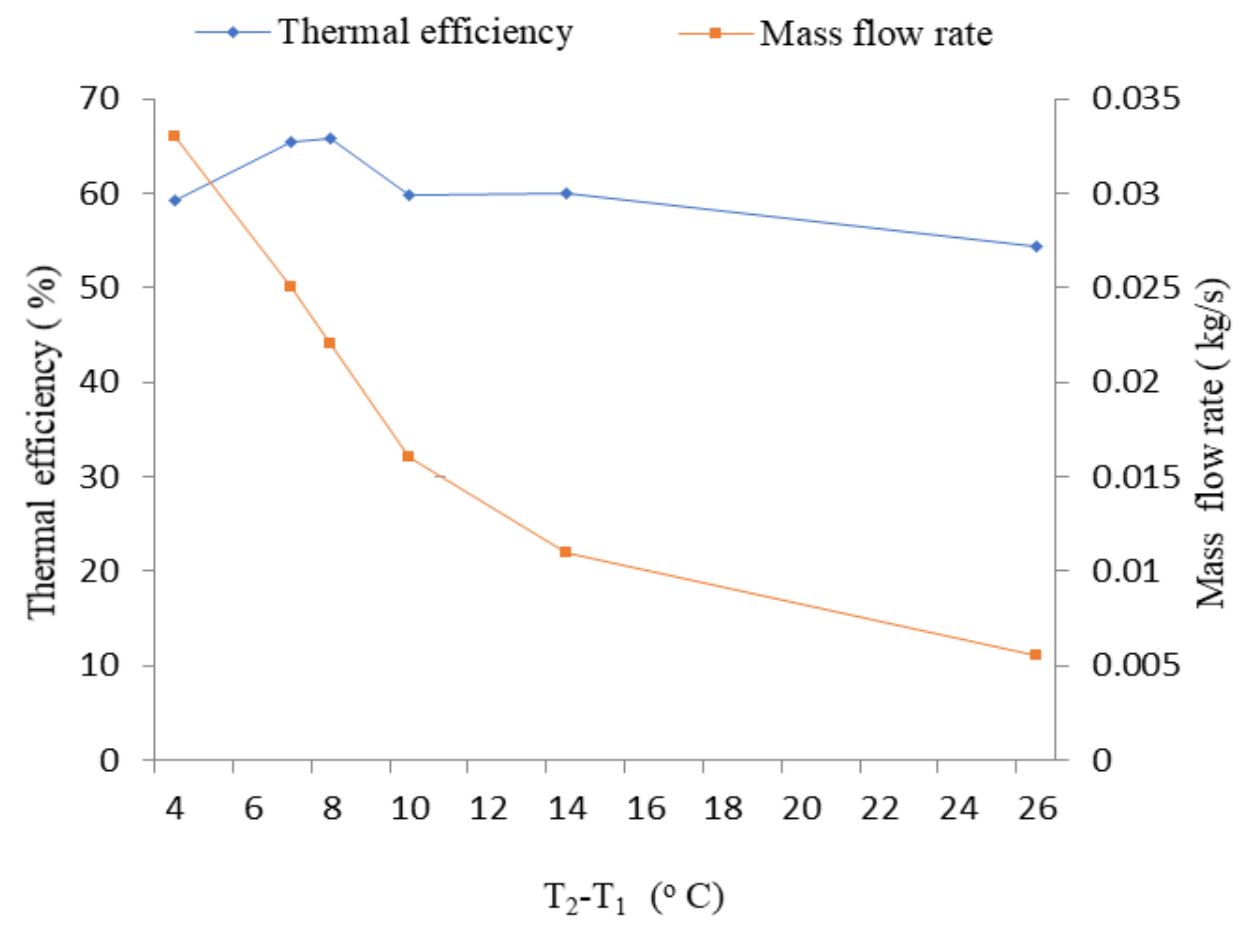

Figure 4. Thermal efficiency and mass flow rate in the solar collector circuit vs. temperature difference $\left(\mathrm{T}_{2}-\mathrm{T}_{1}\right)$.

This kind of energy system sometime requires operating directly without any energy storage. Therefore, a case has been considered and shown in Figure 5, when the tank is empty while the inlet and outlet of the secondary circuit are connected directly to the fresh water supply and the drain, respectively. The mass flow rate in the solar collector circuit is kept constant at $0.022 \mathrm{~kg} / \mathrm{s}$. As can be seen from Figure 5a, the inlet and outlet temperatures of the solar flat collector are strongly affected by the change in the mass flow rate in the secondary circuit. Initially the outlet temperature at the collector is $60{ }^{\circ} \mathrm{C}$ at a mass flow rate of $0.0083 \mathrm{~kg} / \mathrm{s}$ (the lowest flow rate in the secondary circuit) and the temperature difference between the collector inlet and outlet is $8{ }^{\circ} \mathrm{C}$. Then flow rate was increased to $0.031 \mathrm{~kg} / \mathrm{s}, 0.048 \mathrm{~kg} / \mathrm{s}, 0.076 \mathrm{~kg} / \mathrm{s}$, and $0.098 \mathrm{~kg} / \mathrm{s}$ and the system could get into steady state condition. The temperature difference in the inlet and outlet of the collector increased to $11^{\circ} \mathrm{C}$, as we increased the flow rate to $0.031 \mathrm{~kg} / \mathrm{s}$ and after that the increase in flow rate $(0.048 \mathrm{~kg} / \mathrm{s}, 0.048 \mathrm{~kg} / \mathrm{s}, 0.076 \mathrm{~kg} / \mathrm{s}$, and $0.098 \mathrm{~kg} / \mathrm{s})$ have very small almost negligible effect on the temperature difference between the inlet and outlet temperature at the collator. The collector outlet temperature reduces to $47^{\circ} \mathrm{C}$ at a mass flow rate of $0.098 \mathrm{~kg} / \mathrm{s}$. Figure $5 \mathrm{~b}$ shows the thermal efficiency, outlet water temperature in the secondary circuit vs. temperature difference at the inlet and outlet of the collector. The thermal efficiency increases as the mass flow rate increases from $0.0083 \mathrm{~kg} / \mathrm{s}$ to 0.031 $\mathrm{kg} / \mathrm{s}$ from $66.37 \%$ to $91.26 \%$, while further the increase in the mass flow rate (at 0.048 $\mathrm{kg} / \mathrm{s}, 0.076 \mathrm{~kg} / \mathrm{s}$, and $0.098 \mathrm{~kg} / \mathrm{s}$ ) has no effect on the efficiency and is constant at $91.26 \%$. Furthermore, it can be seen from the graph that with the increase in the mass flow rate, the temperature at the outlet of the secondary circuit changes from $49.5^{\circ} \mathrm{C}$ to $31.5^{\circ} \mathrm{C}$. The reduction in the temperature is high initially with the increase in the mass flow rate. The outlet temperatures at $0.0083 \mathrm{~kg} / \mathrm{s}$ to $0.031 \mathrm{~kg} / \mathrm{s}, 0.048 \mathrm{~kg} / \mathrm{s}, 0.076 \mathrm{~kg} / \mathrm{s}$, and $0.098 \mathrm{~kg} / \mathrm{s}$ are $49.5{ }^{\circ} \mathrm{C}, 36^{\circ} \mathrm{C}, 35.3{ }^{\circ} \mathrm{C}, 32.5^{\circ} \mathrm{C}, 31.5^{\circ} \mathrm{C}$, respectively. 


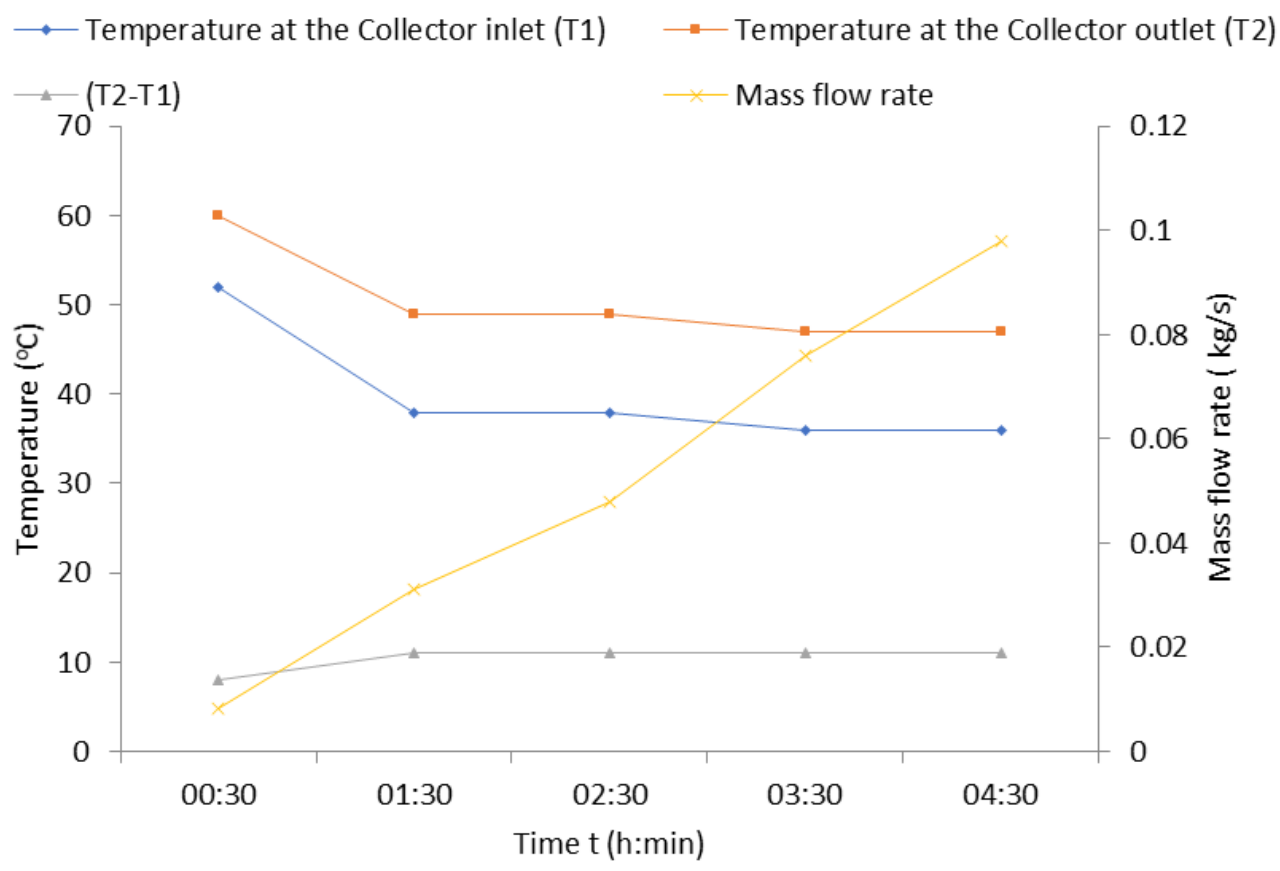

(a)



(b)

Figure 5. The inlet and outlet of the secondary circuit is connected to the fresh water supply and the drain respectively (a) inlet, outlet temperature and mass flow rate in the secondary circuit vs. time (b) Thermal efficiency and mass flow rate in the secondary circuit vs. temperature difference.

The thermal efficiency of the system at various flow rates can help in improving some design parameters. Figure 6 shows the thermal efficiency relationship to the changing mass flow rate in the solar collector circuit to the fixed mass flow rate in the secondary circuit. Figure 6 a shows the thermal efficiency of the solar collector at a constant mass 
flow rate of $0.048 \mathrm{~kg} / \mathrm{s}$ in the secondary circuit while changing the mass flow rate in the primary circuit at six different values i.e. $(0.0055 \mathrm{~kg} / \mathrm{s}, 0.011 \mathrm{~kg} / \mathrm{s}, 0.016 \mathrm{~kg} / \mathrm{s}, 0.022 \mathrm{~kg} / \mathrm{s}$, $0.025 \mathrm{~kg} / \mathrm{s}$ and $0.033 \mathrm{~kg} / \mathrm{s})$. At $0.048 \mathrm{~kg} / \mathrm{s}$ flow rate in the secondary circuit, the thermal efficiency has minimum and maximum values of $67.4 \%$ and $91.26 \%$ at mass flow rates of $0.0055 \mathrm{~kg} / \mathrm{s}$ and $0.022 \mathrm{~kg} / \mathrm{s}$, respectively. As can be seen from the figure that the efficiency increases with the increase in the flow rate to a certain value and then starts decreasing with the mass flow rate. The maximum efficiency is attained at $0.022 \mathrm{~kg} / \mathrm{s}$ and then the values fall to $88.36 \%$ and $85.04 \%$ at $0.016 \mathrm{~kg} / \mathrm{s}$ and $0.011 \mathrm{~kg} / \mathrm{s}$, respectively. The water inlet temperature to the secondary circuit was $27.5^{\circ} \mathrm{C}$ and the outlet temperature varies with mass flow rate between $36{ }^{\circ} \mathrm{C}$ and $33.5{ }^{\circ} \mathrm{C}$ at $0.033 \mathrm{~kg} / \mathrm{s}$ and $0.0055 \mathrm{~kg} / \mathrm{s}$, respectively. Figure $6 \mathrm{~b}$ shows the thermal efficiency of the solar collector at a mass flow rate of $0.062 \mathrm{~kg} / \mathrm{s}$ in the secondary circuit and changing the mass flow rates in the primary circuit at six different values $(0055 \mathrm{~kg} / \mathrm{s}, 0.011 \mathrm{~kg} / \mathrm{s}, 0.016 \mathrm{~kg} / \mathrm{s}, 0.022 \mathrm{~kg} / \mathrm{s}, 0.025 \mathrm{~kg} / \mathrm{s}$, $0.033 \mathrm{~kg} / \mathrm{s})$. At $0.062 \mathrm{~kg} / \mathrm{s}$ flow rate in the secondary circuit, the thermal efficiency has minimum and maximum values of $71.56 \%$ and $88.78 \%$ at mass flow rates of $0.0055 \mathrm{~kg} / \mathrm{s}$ and $0.022 \mathrm{~kg} / \mathrm{s}$, respectively. The water inlet temperature to the secondary circuit is 27.5 ${ }^{\circ} \mathrm{C}$ and the outlet temperature varies between $33.5^{\circ} \mathrm{C}$ and $32{ }^{\circ} \mathrm{C}$ at $0.033 \mathrm{~kg} / \mathrm{s}$ and 0.0055 $\mathrm{kg} / \mathrm{s}$, respectively. Figure $6 \mathrm{c}$ shows the thermal efficiency of the solar collector at a constant mass flow rate of $0.1 \mathrm{~kg} / \mathrm{s}$ in the secondary circuit while changing the mass flow rate in the primary circuit at six different values $(0.055 \mathrm{~kg} / \mathrm{s}, 0.011 \mathrm{~kg} / \mathrm{s}, 0.016 \mathrm{~kg} / \mathrm{s}$, $0.022 \mathrm{~kg} / \mathrm{s}, 0.025 \mathrm{~kg} / \mathrm{s}$ and $0.033 \mathrm{~kg} / \mathrm{s})$.



(a) 


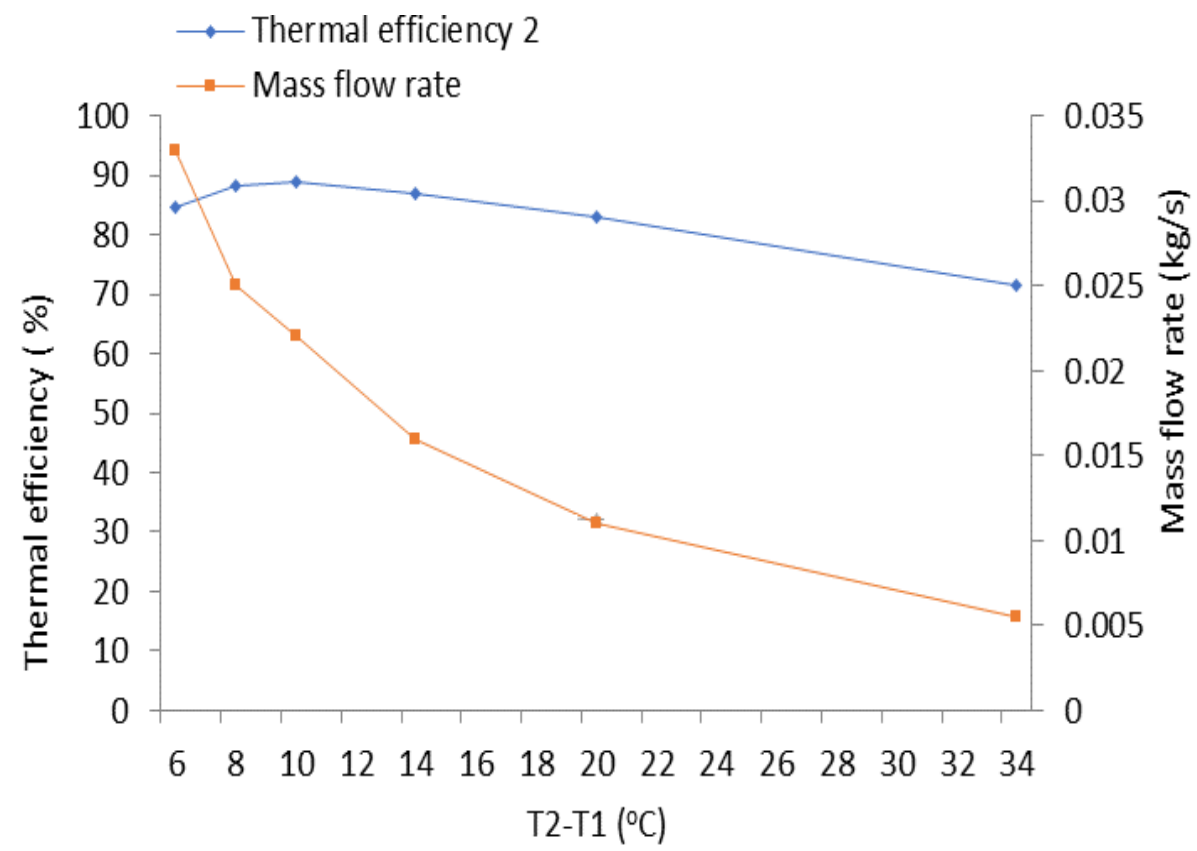

(b)

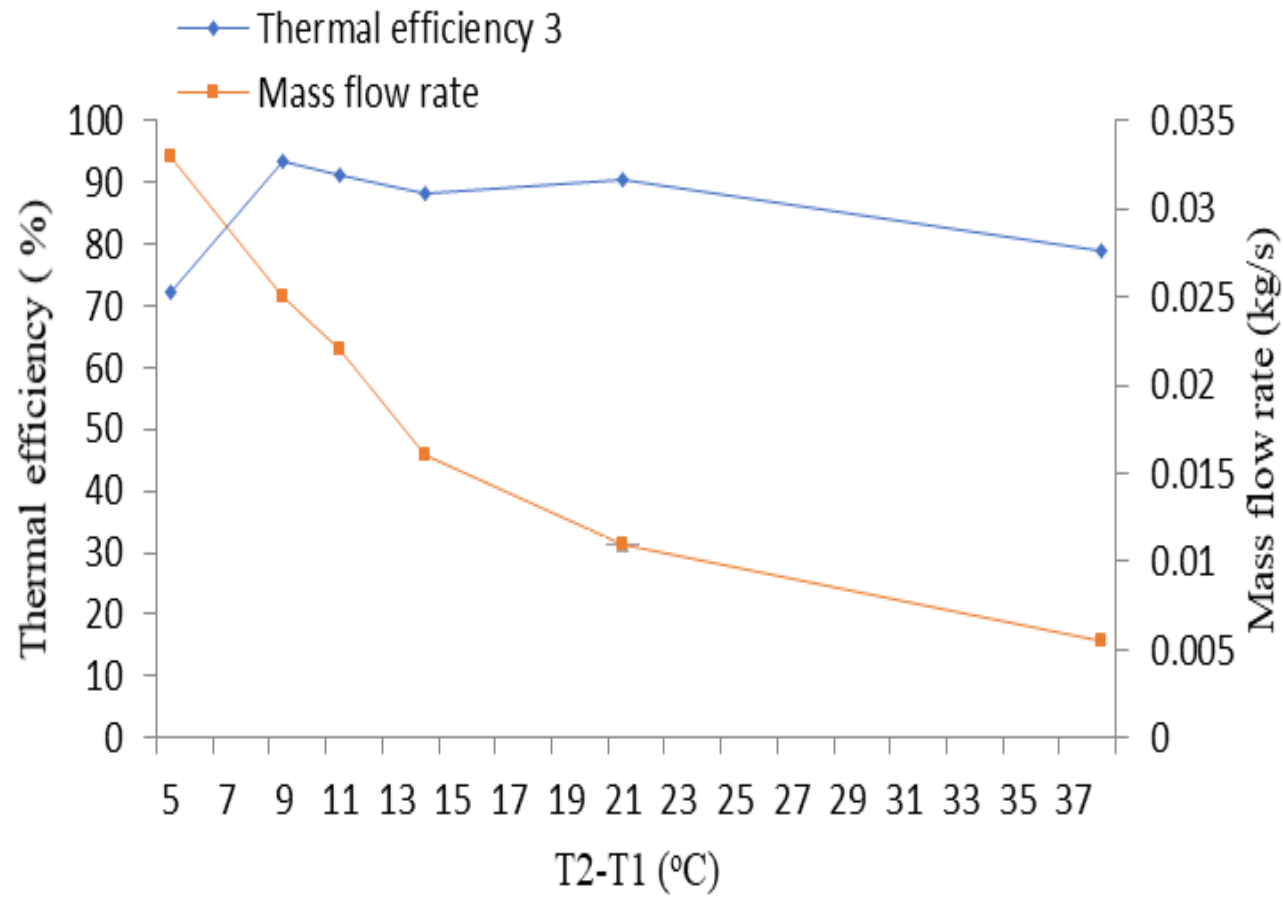

(c)

Figure 6. (a) Thermal efficiency and mass flow rate in the collector circuit vs. temperature difference at mass flow rate of $0.048 \mathrm{~kg} / \mathrm{s}$ in the secondary circuit, (b) Thermal efficiency and mass flow rate in the collector circuit vs. temperature difference at mass flow rate of $0.062 \mathrm{~kg} / \mathrm{s}$ in the secondary circuit, (c) Thermal efficiency and mass flow rate in the collector circuit vs. temperature difference at mass flow rate of $0.1 \mathrm{~kg} / \mathrm{s}$ in the secondary circuit.

All the readings are taken after the system gets into steady state condition. At $0.1 \mathrm{~kg} / \mathrm{s}$ mass flow rate in the secondary circuit, the thermal efficiency has minimum and 
maximum values of $72.18 \%$ and $91.26 \%$ at mass flow rates of $0.033 \mathrm{~kg} / \mathrm{s}$ and $0.022 \mathrm{~kg} / \mathrm{s}$, respectively. In this case the highest flow rate has the lowest efficiency. The water inlet temperature to the secondary circuit is $27.5^{\circ} \mathrm{C}$ and the outlet temperature varies between $32{ }^{\circ} \mathrm{C}$ and $31.5{ }^{\circ} \mathrm{C}$ at $0.033 \mathrm{~kg} / \mathrm{s}$ and $0.0055 \mathrm{~kg} / \mathrm{s}$, respectively. The highest efficiency in all the thee cases $(0.048 \mathrm{~kg} / \mathrm{s}, 0.062 \mathrm{~kg} / \mathrm{s}$ and $0.1 \mathrm{~kg} / \mathrm{s}$ in the secondary circuit) has been attained at $0.022 \mathrm{~kg} / \mathrm{s}$ in the primary circuit. Regarding the outlet water temperature in the secondary circuit, the highest is achieved at $0.048 \mathrm{~kg} / \mathrm{s}$ in the secondary circuit. The variation at different flow rates in the primary circuit to the water outlet temperature is equal to $2.5^{\circ} \mathrm{C}$. The lowest water outlet temperature is attained at $0.1 \mathrm{~kg} / \mathrm{s}$ in the secondary circuit and the variation at different flow rates for the solar collector circuit is only 0.5 ${ }^{\circ} \mathrm{C}$. The difference between the inlet and outlet temperatures in the primary circuit $\left(\mathrm{T}_{2}-\right.$ $\left.\mathrm{T}_{1}\right)$, is in the range of $\left(6^{\circ} \mathrm{C}-32.5^{\circ} \mathrm{C}\right),\left(6.8^{\circ} \mathrm{C}-34.5^{\circ} \mathrm{C}\right)$, and $\left(5.8^{\circ} \mathrm{C}-38.1^{\circ} \mathrm{C}\right)$ for $0.048 \mathrm{~kg} / \mathrm{s}$, $0.062 \mathrm{~kg} / \mathrm{s}$, and $0.1 \mathrm{~kg} / \mathrm{s}$ in the secondary circuit respectively. The total uncertainties of the measurements of temperature, pressure, solar radiation, flow rate and electrical power are estimated to be $\pm 2.56 \%, 4.12 \%, \pm 2.31, \pm 3.12 \%$, and $1.23 \%$,respectively. Figure 7 shows the variation of thermal efficiency in $\%$, which was also correlated with a coefficient of determination as follows:

$$
\eta_{\text {scol }}=-0.906 x+101.2
$$

whereas $\mathrm{x}$ can be calculated as follows;

$$
x=\left[\frac{\left(T_{2}-T_{1}\right)}{2}-T_{0}\right]
$$

where $T_{1}$ and $T_{2}$ are the inlet and outlet temperatures of the fluid, while $T_{0}$ is the ambient temperature. The trend of the exergy efficiencies of the solar collector under consideration is shown in Figure 8 with the help of the exergy efficiency curve for the solar collector.



Figure 7. Thermal efficiency curve for the solar collector considered. 


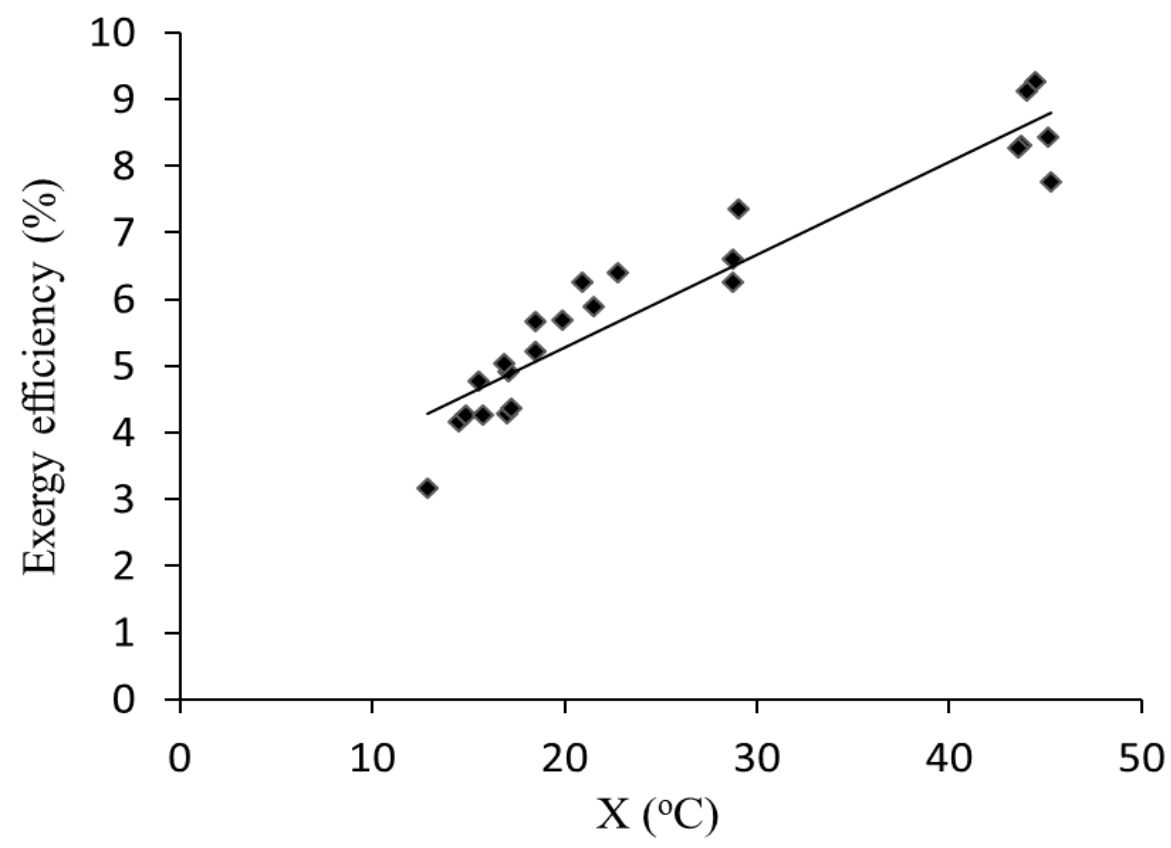

Figure 8. Exergy efficiency curve for the solar collector.

\section{CONCLUSIONS}

Energy storage at domestic level and its use at a time when needed is very crucial. This can help in the cost reduction of the buildings in terms of energy, climate change due to burning of extra fossil fuels; avoiding of the extra load on grid. The idea of smart grid and maximum integration of the renewable energy can be assisted by the efficient and compact energy storage. The domestic level which consumes almost $50 \%$ of the total energy for Domestic hot water (DHW) and space heating. In this study a controlled lab rotary environmental conditions have been created to test the behavior of the solar flat collectors with storage in different case studies. The study is based on the energy and exergy analysis methods. Exergy analysis, which is based on the second law of thermodynamics, represents the quality of energy and involves the irreversibility while analyzing the system efficiency. The following concluding remarks can be made:

- The greatest irreversibility rate occurred at the solar collector with a value of 0.990 $\mathrm{kW}$ and the efficiency value was determined to be $13.01 \%$ on the exergetic product/ fuel basis.

- The exergy efficiency for the solar collector was found to be in the range of $3.17 \%$ $-9.26 \%$ on the net rational basis definition.

- The mass flow rate in the solar collector circuit and the secondary circuit had a strong effect on the energy and exergy efficiencies and there was an optimum value at which the system could be operated. The optimum value for the solar collector circuit was found to be $0.022 \mathrm{~kg} / \mathrm{s}$.

- The thermal efficiency increased as the mass flow rate increased from $0.0083 \mathrm{~kg} / \mathrm{s}$ to $0.031 \mathrm{~kg} / \mathrm{s}$ from $66.37 \%$ to $91.26 \%$, while further increase in mass flow rate (at $0.048 \mathrm{~kg} / \mathrm{s}, 0.076 \mathrm{~kg} / \mathrm{s}$, and $0.098 \mathrm{~kg} / \mathrm{s}$ ) had no effect on the efficiency and was constant at $91.26 \%$. 
- The sustainability index values for the solar collector, the heat exchanger, the pump and the overall system were obtained to be $1.149,3.317,1.587$, and 1.254 , respectively.

The study can be extended to various types of buildings and conducting a survey for the water consumption pattern depending on the number of people living at homes (age factor is also important while estimating the heated water consumption). By getting enough information of the energy (electricity \& heating) consumption depending on the type of buildings the system can be integrated. This study will provide some basic measured parameters as an input to the integrated system at different weather conditions. Additionally, this could be extended to Nano-fluids for the possible efficiency and heat transfer coefficient improvement by comparing with the cases considered here.

\section{ACKNOWLEDGEMENTS}

The authors are grateful to the deanship of scientific research Imam Abdul Rahman bin Faisal University for the test facility and the valuable feedback from the reviewers to improve the quality of the paper.

\section{NOMENCLATURE}

$\begin{array}{ll}\dot{E} & \text { energy rate }(\mathrm{kW}) \\ \dot{E} x & \text { exergy rate }(\mathrm{kW}) \\ \dot{F} & \text { exergetic fuel rate }(\mathrm{kW}) \\ h & \text { specific enthalpy }(\mathrm{kJ} / \mathrm{kg}) \\ \dot{I P} & \text { Improvement potential rate }(\mathrm{kW}) \\ \dot{m} & \text { mass flow rate }(\mathrm{kg} / \mathrm{s}) \\ \mathrm{P} & \text { Pressure } \\ \dot{P} & \text { Exergetic product rate }(\mathrm{kW}) \\ \mathrm{R} & \text { Calculated result } \\ \mathrm{RI} & \text { Relative irreversibility } \\ \mathrm{S} & \text { Specific entropy }(\mathrm{kJ} / \mathrm{kg}) \\ \mathrm{SI} & \text { Sustainability index } \\ \mathrm{T} & \text { Temperature }(\mathrm{K}) \\ \mathrm{U} & \text { Overall heat transfer coefficient }(\mathrm{W} / \mathrm{K}) \\ \mathrm{U} & \text { Uncertainty } \\ \mathrm{u} & \text { Useful } \\ \dot{W} & \text { Work rate or power }(\mathrm{kW}) \\ \text { Greek letters } \\ \psi & \text { specific exergy }(\mathrm{kJ} / \mathrm{kg}) \\ \varepsilon & \text { exergy efficiency }(\%) \\ \eta & \text { energy efficiency }(\%) \\ \text { Indices } & \\ 0 & \text { reference state } \\ 1 & \text { inlet state point }\end{array}$


[1] Aste N, Del Pero C, Adhikari RS, Marenzi G. Effectiveness and weaknesses of supporting policies for solar thermal systems-A case-study. Sustainable Cities and Society. 2015; 14: 146-53.

[2] Gilani SE, Al-Kayiem HH, Woldemicheal DE. Effect of conical pin arrangement on heat transfer efficiency of a free convective solar air heater. Journal of Mechanical Engineering and Sciences (JMES). 2016; 10: 2053- 64.

[3] Sansaniwal SK, Kumar M. Analysis of ginger drying inside a natural convection indirect solar dryer: An experimental study. Journal of Mechanical Engineering and Sciences (JMES). 2015; 9: 1671- 85.

[4] Zambrana-Vasquez D, Aranda-Usón A, Zabalza-Bribián I, et al. Environmental assessment of domestic solar hot water systems: a case study in residential and hotel buildings. Journal of Cleaner Production. 2015; 88: 29-42.

[5] Panaras G, Mathioulakis E, Belessiotis V. A method for the dynamic testing and evaluation of the performance of combined solar thermal heat pump hot water systems. Applied Energy. 2014; 114: 124-34.

[6] Jafarkazemi F, Ahmadifard E. Energetic and exergetic evaluation of flat plate solar collectors. Renewable Energy. 2013; 56: 55-63.

[7] Ge Z, Wang H, Wang H, Zhang S, Guan X. Exergy Analysis of Flat Plate Solar Collectors. Entropy. 2014; 16: 2549.

[8] Koroneos C, Tsarouhis M. Exergy analysis and life cycle assessment of solar heating and cooling systems in the building environment. Journal of Cleaner Production. 2012; 32: 52-60.

[9] Kashyap Y, Singh A, Raja Sekhar Y. Exergy Analysis of a Flat Plate Solar Collector With Grooved Absorber Tube Configuration Using Aqueous ZnOEthylene Glycol. Journal of Solar Energy Engineering. 2018; 140: 061011-10.

[10] Moghadam H, Deymeh SM. Determination of optimum location and tilt angle of solar collector on the roof of buildings with regard to shadow of adjacent neighbors. Sustainable Cities and Society. 2015; 14: 215-22.

[11] Greening B, Azapagic A. Domestic solar thermal water heating: A sustainable option for the UK? Renewable Energy. 2014; 63: 23-36.

[12] Abdelghani-Idrissi MA, Khalfallaoui S, Seguin D, Vernières-Hassimi L, Leveneur S. Solar tracker for enhancement of the thermal efficiency of solar water heating system. Renewable Energy. 2018; 119: 79-94.

[13] Wu W, Dai S, Liu Z, et al. Experimental study on the performance of a novel solar water heating system with and without PCM. Solar Energy. 2018; 171: 604-12.

[14] Mahendran M, Lee GC, Sharma KV, Shahrani A, Bakar RA. Performance of evacuated tube solar collector using water-based titanium oxide nanofluid. Journal of Mechanical Engineering and Sciences (JMES) 2012; 3: 301-10.

[15] Srinivasa RG, Sharma KV, Chary SP, et al. Experimental study on heat transfer coefficient and friction factor of $\mathrm{Al} 2 \mathrm{O} 3$ nanofluid in a packed bed column. Journal of Mechanical Engineering and Sciences. 2011; 1: 1-15. 
[16] Tahseen M, Ishak, Rahman M. A numerical study of forced convection heat transfer over a series of flat tubes between parallel plates Journal of Mechanical Engineering and Sciences (JMES). 2012; 3: 271- 80.

[17] Baneshi M, Bahreini SA. Impacts of hot water consumption pattern on optimum sizing and techno-economic aspects of residential hybrid solar water heating systems. Sustainable Energy Technologies and Assessments. 2018; 30: 139-49.

[18] Eu Commission. An EU strategy on heating and cooling Commission of the European Communities, Brussels (2016) https://ec.europa.eu/energy/sites/ener/files/documents/1_EN_ACT_part1_v14.pd f, Accessed 24th October 2018.

[19] Brandoni C, Shah N, Vorushylo I, Hewitt N. Poly-generation as a solution to address the energy challenge of an aging population. Energy Conversion and Management,. 2018; 171: 635-46.

[20] Ceylan I. Energy and exergy analyses of a temperature controlled solar water heater. Energy and Building. 2012; 47: 630-5.

[21] Duffie JA, Beckman WA. Solar Engineering of Thermal Process. . New York: Wiley, 1991.

[22] Öztürk HH. Experimental determination of energy and exergy efficiency of the solar parabolic-cooker. Solar Energy. 2004; 77: 67-71.

[23] Petela R. Exergy analysis of the solar cylindrical-parabolic cooker. Solar Energy. 2005; 79: 221-33.

[24] Kotas TJ. The Exergy Method of Thermal Plant Analysis. UK.: Anchor Brendon Ltd., Tiptree, Essex, 1985.

[25] Van Gool, W. Energy policy: Fairy tales and factualities. In: Innovation and Technology-Strategies and Policies, Soares, O. D. D., Martins da Cruz, A., Costa Pereira, G., Soares, I. M. R. T., and Reis, A. J. P. S, editors. Dordrecht: Kluwer. 93- 105, 1997.

[26] Abid M, Hepbasli A. Dynamic Exergetic Analysis and Evaluation of Photovoltaic Modules. Energy Sources, Part A: Recovery, Utilization, and Environmental Effects. 2015; 37: 2271-84. 